\title{
The Leadership and Management Characteristics of Volleyball Coaches in Jordan
}

\author{
By \\ Dr. Jamal Ali Said Rababa'a, \\ Sports Science College, Mu'tah University \\ Dr. Fidaa ahmad mehyair \\ Sports Science College, Mu'tah University
}

$-v \circ \Delta-$ 


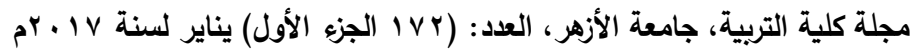

\title{
The Leadership and Management Characteristics of Volleyball Coaches in Jordan
}

\begin{abstract}
:
This study aimed at identifying the leadership and management characteristics of volleyball coaches in Jordan from the perspective of the players according to the variables of (the club and the training age).

The sample of study was chosen randomly. It consisted of 94 players and constituted about $78 \%$ of the total population. The researchers used the descriptive approach with its survey image. The scale of the Leadership and management characteristics was used. The scale consisted of 43 items which were distributed to four domains (The personal domain, the professional domain, the social domain and the scientific domain). The means, standard deviations, One-Way Anova and Scheffe test for multiple comparisons were used.

The results of study showed that the leadership and management characteristics among the coaches of volleyball were of a high degree. The study results also showed that there are statistically significant differences in the leadership and management characteristics for the responses of the players with regard to the variable of training age in favor of (less than 5 years).
\end{abstract}

The researchers recommends about the necessity of using the leadership and management characteristics of the coaches when planning for the training courses, as well as putting them within the content of the programs for promoting the coaches in the field of volleyball.

Keyword: Leadership, management, volleyball, coaches, Jordan 


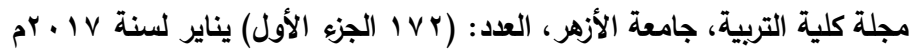

Introduction:

The development of administration and the breadth of its role in the modern state has led to an increase in the need for a constructive leaderships that can perform their duties wisely, efficiently and faithfully; and increasing demand on leaders creators who are able to lead the development process and push it forward to the highest possible degree of efficiency, effectiveness and production (Kanaan, 1999).

The coach is one of the leaders in the field of sports through his work and role as an administrator and a leader who works with sports teams and possesses the managerial and leadership characteristics that qualify him for that. Therefore, his influential role in achieving the sporting achievements in the different situations which he experiences during competition and training requires him to have a variety of distinctive leadership and management characteristics that show his behaviors and his ability to use the different leadership styles depending on the nature and importance of sports situations that he experiences (Abu Zima', 2011).

Undoubtedly, people in these days realize the role of coaches in team sports administration, and the extent of their influence and effectiveness in getting to the highest levels of achievement with their sport teams. Sports teams in the modern era also face many difficulties and challenges in the various competitive championships. All this comes through the different behaviors, either by the coach or the players. The coach is considered as the basic axis in many situations. Therefore, he must have many of the leadership and management characteristics that make him distinctive from the other ordinary people; and so, the coach must be prepared in a special way which is characterized by efficiency as well as specialization in the field of work, by providing him with the theoretical and practical knowledge and information (Ali, 2003).

Each athlete who practices the Sports at the competitive levels aims to achieve the maximum possible level of achievement for himself, but the athlete can't achieve this goal unless he cooperates and works closely with the coach who has a great deal 
of theoretical knowledge, great practical experience, positive management attributes, interconnected mentality operations, as well as a conscious administration that pushes him to work until he paves the way to the athletes to achieve their goal (Abdel Maksoud, 1995).

At the present time, Sports Management needs a flexible and a dynamic type of administration that is able to face the difficult challenges to the athletic coach. Although some coaches are characterized by technical capacities in the management and leadership of the sports teams, as well as their ability to perform their duties with Knowledge, efficiency and dedication, the increased interest in sports teams and their results has increased the need to competencies that are able to lead the athletes to achieve the desired goals (Bani hani, 2007).

The administrative processes, such as the process of leadership, communication and change as well as the processes of group dynamics, team building and conflicts resolving are considered administrative processes that need the administrators and leaders to develop the skills that help in a good performance and effectiveness regarding their implementation and monitoring. These processes are also considered as the essence of the administrative process (Al-Massad, 2003).

The person who wants to be a successful leader needs to determine his best attributes and develop them, he also needs to have a training on how to communicate them to others, and should realize that the best way to influence others is by focusing on the distinctive traits that he has (Chapman,2001). That the distinguished leaders can attract others to help them achieve success; the leader can be successful in achieving his objectives through others by making them feel that he helps them to achieve their goals, and this feeling motivates them accept him, and look for the success his task (Cohen, 2001 ).

The successful coaches who dedicate all his attributes as well as leadership and management skills in order to achieve success in the implementation of the tasks, thus achieves the goals of the sporting institution that he belongs to. this depends on his 


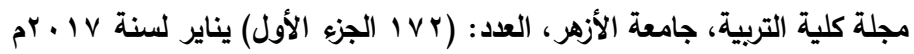

relationship with his team members, and the effectiveness of his ability to invest and employ their abilities to implement his prepared plans, as well as issued directions and instructions for doing his tasks and duties (Al Kubaisi, 2010).

The coach is one of the leaders in the field of sports, through his work and his role as an administrator and leader who works with sports teams, and has the management and leadership characteristics that qualify him for that, and thus his influential role in making sports achievements in the different situations, that he experiences during training or competition, which requires having a variety of distinctive leadership and management characteristics that show his behaviors and ability to use the different leadership styles.

Leadership and management characteristics play a vital role in the ability of the coach to guide the players and motivate them forward towards achieving the best performance levels, they become more motivated to achieve high athletic achievements, and so the importance of this study lies in identifying the leadership and management characteristics of coaches of volleyball in Jordan from the viewpoint of the athletes themselves.

The coach is considered as the primary axis in too many situations. and who builds the administrators, coaches and referees. team and preparing the players to reach their highest levels and achieve the sports championships. and he must have many of the leadership and management characteristics that make him distinctive from the other ordinary people. and must to be preparing in a special way characterized by efficiency and specialization in the field of work.

This study is very important to identify the management and leadership characteristics for the coaches of volleyball in Jordan , hoping that the current study would be helpful for all those who are interested in this field, which will ultimately be evident in their achievement in the competitions and championships, particularly in the domain of volleyball.

\section{The Objectives Study:}


This study aimed to identify the leadership and management characteristics of volleyball coaches in Jordan from the perspective of the players Depending on the variables (the club, training age).

\section{Study Questions:}

1. What are the most important leadership and management characteristics of volleyball coaches in Jordan from the perspective of the players?

2. Are there statistically significant differences at the significance level $(\alpha \leq 0.05)$ in the leadership and management characteristics of coaches for the coaches of volleyball in Jordan from the perspective of the players Depending on the variables (the club, training age).

\section{Methodology:}

The study sample consisted of 94 players, who represent 10 clubs according to the records of the Jordanian federation of volleyball who participated in the league championship for the 2016/2015 season. they were randomly divided. Table (1) illustrates it.

Table (1). The distribution of the sample Depending on the variables of the study

\begin{tabular}{|c|c|c|c|}
\hline Number & The club & Number of players & $\%$ \\
\hline 1 & Al-Wehdat & 12 & 12.7 \\
\hline 2 & Shabab Al-Hussein & 12 & 12.7 \\
\hline 3 & Wadi Mousa & 10 & 10.7 \\
\hline 4 & Al-Karmel & 10 & 10.7 \\
\hline 5 & Al-Baqaa & 10 & 10.7 \\
\hline 6 & Aira & 8 & 8.5 \\
\hline 7 & Almahatta & 8 & 8.5 \\
\hline 8 & Deiralla & 8 & 8.5 \\
\hline 9 & Maleeh & 8 & 8.5 \\
\hline 10 & Al-awda & 8 & 8.5 \\
\hline \multicolumn{2}{|r|}{ Total } & 94 & $100 \%$ \\
\hline
\end{tabular}




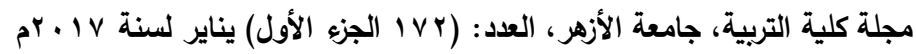

The researchers used the questionnaire which was designed by Bani Hani (2007) about leadership and management characteristics. The questionnaire consisted of 63 items which were distributed to four domains (the personal domain (15 items), professional domain (20 items), the social domain (15 items), and the scientific domain (13 items). The scale was judged by 10 specialists of those who have good expertise and competence.

The questionnaires were retrieved from the specialists about the scale of leadership and management characteristics with a total of 10 questionnaires. The achievements of those teams were obtained during their participation in the eleventh Arab Championship.

The researchers used the Likert scale to design the items of the questionnaire which the response ranges from (too high $\mathbf{( 4 . 0 0}$ and above), high (from 3.60-less than 4.00), moderate (from 3.20 less than 3.60), low (from 2.80 - less than 3.20), too low (less than $2.80)$ ) which were represented by $(5,4,3,2,1)$. (Al-lemon, 2013; Bani Hani, 2007)

The questionnaire was presented to specialists in the field of sports sciences who confirmed the validity of the questionnaire. To verify the questionnaire reliability, the researchers calculated its reliability coefficients by using t-test and re-test on samples others than the sample of the study with a value of correlation coefficient $(\mathbf{0 . 8 8})$.

\section{The study variables:}

- The independent variables: Four domains (personal domain, professional domain, social domain, and scientific domain) among the coaches of volleyball in Jordan.

- The dependent variables: - Ten clubs (Al-Wehdat, Shabab Al-Hussein, Wadi Mousa, Al-Karmel, Al-Baqaa, Aira, Al mahatta, Deir alla, Maleeh, Al-awda).

- The age of training: Three levels (less than 5 years; 5-10 years; and more than 10 years).

The researchers used the SPSS package to process the data statistically (means, standard deviations, Manova, Three Way 
Anova, Scheffe' Test, coefficient Pearson's correlation) to answer the questions of study.

\section{Results and discussion:}

To answer the first question "What are the leadership and management characteristics among the coaches of volleyball in Jordan from the perspective of the players?. The arithmetic means and standard deviations for the estimations of the individuals of the study sample were calculated regarding the domains of the leadership and management characteristics among the coaches of volleyball in Jordan as shown in Table (2).

Table (2). The arithmetic means and standard deviations for the leadership and management characteristics among the coaches of volleyball in Jordan from the perspective of

\begin{tabular}{|c|c|c|c|c|c|}
\hline The Rank & No & Domain & Md & Sd & $\begin{array}{c}\text { Characteristic } \\
\text { Degree }\end{array}$ \\
\hline 1 & 3 & The social & 3.75 & .56 & High \\
\hline 2 & 1 & The personal & 3.73 & .54 & High \\
\hline 3 & 2 & The professional & 3.67 & .51 & High \\
\hline 4 & 4 & The scientific & 3.65 & .49 & High \\
\hline \multicolumn{3}{|c|}{ The total average } & 3.70 & .41 & High \\
\hline
\end{tabular}

Table (2) illustrates that all domains of leadership and management characteristics for the coaches from the perspective of the players were with high degrees, in which the social domain of volleyball in Jordan was in the first rank with a mean of (3.75) and standard deviation (0.56), and Personal domain was in the second rank with an arithmetic mean of (3.73) and standard deviation of (0.54). The professional domain was in the third rank with a mean of (3.67) and a standard deviation of $(0.51)$ while the scientific domain was in the last rank with a mean of (3.65) and a standard deviation of (0.49). The arithmetic mean for estimates of the study sample individuals regarding the total the domains of 


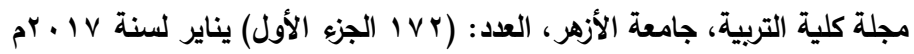

leadership and management characteristics for the questionnaire was (3.70) with a standard deviation of (0.4). This corresponds to a high degree of the leadership and management characteristics.

These results agreed with Rosenberg, 1988; Al-Lemon, 2013, who suggested that the leadership and management behavior level was of a high level, while the results disagree with Shtiwi, 2012; Bani Hani, 2007, who suggested that the leadership and management behavior level was of a moderate level.

The means and standard deviations for the estimates of the study sample individuals regarding the domains of leadership and management characteristics as follows: (social domain, personal domain, professional domain, and scientific domain). Tables $(3,4$, $5,6)$ illustrated it.

Table (3). The arithmetic means and standard deviations for the estimates of the study sample individuals regarding the social domain in a descending order

\begin{tabular}{|c|c|c|c|c|}
\hline No & Items & Md & Sd & $\begin{array}{c}\text { Characteristic } \\
\text { Degree }\end{array}$ \\
\hline 12 & $\begin{array}{l}\text { Interested in making social } \\
\text { relationships with the players }\end{array}$ & 4.43 & .71 & Too high \\
\hline 14 & $\begin{array}{l}\text { Promotes friendship } \\
\text { relationships with his players }\end{array}$ & 4.38 & .70 & Too high \\
\hline 10 & $\begin{array}{l}\text { Helps in solving the problems } \\
\text { of his players }\end{array}$ & 4.35 & .74 & Too high \\
\hline 8 & $\begin{array}{l}\text { Interested in raising } \\
\text { the morale of the payers }\end{array}$ & 4.34 & .70 & Too high \\
\hline 6 & $\begin{array}{l}\text { Interested in the different } \\
\text { national celebrations }\end{array}$ & 4.30 & .75 & Too high \\
\hline 2 & Affects positively on the players & 4.29 & .70 & Too high \\
\hline 4 & $\begin{array}{l}\text { Takes the customs } \\
\text { and the social traditions } \\
\text { in consideration }\end{array}$ & 4.14 & .70 & Too high \\
\hline 7 & $\begin{array}{c}\text { Promotes competitiveness } \\
\text { between the players }\end{array}$ & 3.37 & 1.03 & Above average \\
\hline 5 & $\begin{array}{l}\text { Interested in the religious } \\
\text { celebrations }\end{array}$ & 3.35 & 1.01 & Above average \\
\hline 9 & Listens to players & 3.35 & .97 & Above average \\
\hline 11 & $\begin{array}{c}\text { Respects and appreciates } \\
\text { the players }\end{array}$ & 3.34 & .96 & Above average \\
\hline
\end{tabular}




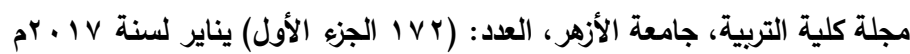

\begin{tabular}{|c|c|c|c|c|}
\hline 1 & Trusts the players & 3.32 & 1.05 & Above average \\
\hline 15 & Keeps the secrets off the players & 3.19 & .90 & Moderate \\
\hline 13 & $\begin{array}{c}\text { Promotes the teamwork } \\
\text { among the players }\end{array}$ & 3.19 & .91 & Moderate \\
\hline 3 & $\begin{array}{c}\text { Deals equally and fairly } \\
\text { with the players }\end{array}$ & 2.84 & 1.12 & Moderate \\
\hline \multicolumn{2}{|c|}{ The total domain } & 3.75 & .56 & High \\
\hline
\end{tabular}

Table (3) illustrates that item number (12) which includes 'Interested in making social relationships with the players' was in the first rank with a high degree and with an arithmetic mean of (4.43) and a standard deviation of ( 0.71$)$. The researcher believes that the players of the clubs do not reach to team of volleyball unless they have featured abilities physically, skillfully mentally, and psychologically. The role of the coach is clear in understanding the nature of his work perfectly by seeking to increase the cooperation and build a collective constructive relationships which achieve the goals that he seeks, especially that he is training a team game which requires building social and strong relationships with the players, especially in the absence of psychological specialist in clubs. Item (3) which included 'Deals equally and fairly with the players' was in the last rank with an arithmetic mean of (2.84) and a standard deviation of(1.12).

The researcher attributes the case that most the coaches of volleyball are of different levels regarding training and that the relationship between the coach and the player is a business relationship, in which the coach performs the training tasks and the player, in turn, wins the championship. The arithmetic mean for the estimates of the sample individuals in this domain as a whole was (3.75) with a standard deviation of (0.56). This corresponds to a high degree of estimating the leadership and management characteristics.

Table (4). The arithmetic means and standard deviations for the estimates of the study sample individuals regarding the personal domain in a descending order

\begin{tabular}{|c|c|c|c|c|}
\hline No & Items & Md & Sd & $\begin{array}{c}\text { Characteristic } \\
\text { degree }\end{array}$ \\
\hline 13 & Self confident & $\mathbf{4 . 4 7}$ & $\mathbf{. 7 3}$ & Too high \\
\hline
\end{tabular}




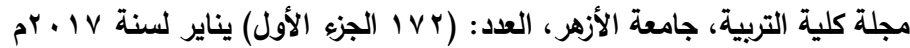

\begin{tabular}{|c|c|c|c|c|}
\hline \hline No & Items & Md & Sd & $\begin{array}{c}\text { Characteristic } \\
\text { degree }\end{array}$ \\
\hline 11 & Faithful in his work & 4.42 & .74 & Too high \\
\hline 9 & Has self motivation to work & 4.29 & .60 & Too high \\
\hline 7 & $\begin{array}{c}\text { Has self control in } \\
\text { the critical situations }\end{array}$ & 4.27 & .72 & Too high \\
\hline 3 & Has the ability to make decisions & 4.22 & .67 & Too high \\
\hline 5 & $\begin{array}{c}\text { Flexible in dealing } \\
\text { with the players }\end{array}$ & 4.13 & .75 & Too high \\
\hline 15 & $\begin{array}{c}\text { Has objectivity in selecting } \\
\text { the players }\end{array}$ & 4.11 & .77 & Too high \\
\hline 12 & Has a Smart appearance & 3.53 & 1.04 & Above verage \\
\hline 10 & $\begin{array}{c}\text { gives a good example } \\
\text { in his deeds for the Players }\end{array}$ & 3.34 & 1.06 & Above verage \\
\hline 8 & $\begin{array}{c}\text { Intelligent in his } \\
\text { administration of the team }\end{array}$ & $\mathbf{3 . 2 6}$ & $\mathbf{1 . 0 5}$ & Above verage \\
\hline 6 & Has a good behavior & $\mathbf{3 . 2 3}$ & $\mathbf{1 . 1 5}$ & Above verage \\
\hline 1 & Has a sense of humor & $\mathbf{3 . 2 2}$ & $\mathbf{1 . 0 2}$ & Above verage \\
\hline 2 & $\begin{array}{c}\text { Honest in achieving } \\
\text { his promises to the players }\end{array}$ & $\mathbf{3 . 1 9}$ & .96 & Moderate \\
\hline 14 & $\begin{array}{c}\text { Courageous in confronting } \\
\text { his players }\end{array}$ & $\mathbf{3 . 1 4}$ & .94 & Moderate \\
\hline 4 & deals fairly with the players & $\mathbf{3 . 0 2}$ & $\mathbf{. 9 8}$ & Moderate \\
\hline & The total domain & $\mathbf{3 . 7 3}$ & .54 & High \\
\hline
\end{tabular}

Table (4) illustrates that item (13) about self confidence was in the first rank with a degree of too high, arithmetic mean of (4.47) and a standard deviation of $(0.73)$. The researcher illustrates that self confidence is due to the continuous and good preparation that the coach gained through the training courses, lectures and workshops that relate to the game of volleyball as well as the national and international championships. Self confidence also comes as a result of dealing with few players, the respect and appreciation to the coaches decisions, the coach's honesty in doing his tasks as well as having the ability to make decisions and shoulder responsibility, as the player becomes creative and successful if he feel that his coach is self confident, courageous in confronting his players and has the intelligence in managing his team. The coach's self confidence is considered as a 
basic element in promoting the sense of winning, improving the achievement among the players as well as promoting their positive view towards him.

Item (4) which includes dealing fairly with the players was ranked in the last place with a medium degree and with an arithmetic mean of (3.02) and a standard deviation of (0.98). In this context, the researcher asserts that the players' desire to participate in competitions at the personal level provide them with imaginations and beliefs that the coach distinguishes between the players and doesn't deal fairly with them. The arithmetic mean for the estimates of the sample individuals in this domain as a whole was( 3.73$)$ with a standard deviation of (0.54). This corresponds to a high degree of estimating the leadership and management characteristics.

Table (5). The arithmetic means and standard deviations for the estimates of the study sample individuals regarding the professional domain in a descending order

\begin{tabular}{|c|c|c|c|c|}
\hline No & Items & Md & Sd & $\begin{array}{c}\text { Characteristic } \\
\text { degree }\end{array}$ \\
\hline 12 & $\begin{array}{c}\text { Serious in giving instruction } \\
\text { to the players }\end{array}$ & 4.48 & .71 & Too high \\
\hline 4 & $\begin{array}{c}\text { Attempts to provide } \\
\text { a better environment } \\
\text { for volleyball training }\end{array}$ & 4.41 & .69 & Too high \\
\hline 6 & $\begin{array}{c}\text { Has the ability to adapt } \\
\text { with work stressors }\end{array}$ & 4.40 & .65 & Too high \\
\hline 10 & $\begin{array}{c}\text { Documents the decisions } \\
\text { that he makes }\end{array}$ & 4.34 & .76 & Too high \\
\hline 8 & $\begin{array}{c}\text { Gives opportunity } \\
\text { for the talented players }\end{array}$ & 4.33 & .74 & Too high \\
\hline 14 & $\begin{array}{c}\text { Attempts to promote honesty } \\
\text { among the players }\end{array}$ & 4.29 & .76 & Too high \\
\hline 2 & Tends to innovate in his work & 4.28 & .74 & Too high \\
\hline 20 & $\begin{array}{c}\text { Has a good experience } \\
\text { in the field of training }\end{array}$ & 4.28 & .72 & Too high \\
\hline 16 & Has the ability to observe & 4.26 & .72 & Too high \\
\hline
\end{tabular}




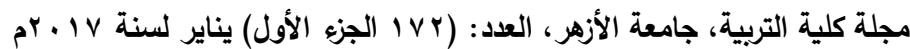

\begin{tabular}{|c|c|c|c|c|}
\hline \hline No & Items & Md & Sd & $\begin{array}{c}\text { Characteristic } \\
\text { degree }\end{array}$ \\
\hline 18 & $\begin{array}{c}\text { Has the ability to show } \\
\text { the players' advantages }\end{array}$ & 4.24 & .74 & Too high \\
\hline 19 & $\begin{array}{c}\text { Respects the sports regulations } \\
\text { in doing his tasks }\end{array}$ & 3.39 & 1.00 & Above verage \\
\hline 3 & Develops himself professionally & 3.27 & 1.07 & Above verage \\
\hline 7 & Fair in distributing motivation & 3.17 & 1.09 & Moderate \\
\hline 17 & $\begin{array}{c}\text { Has the ability of organization } \\
\text { theng }\end{array}$ & 3.17 & 1.00 & Moderate \\
\hline 11 & $\begin{array}{c}\text { Attempts to achieve goals } \\
\text { according to priority }\end{array}$ & 3.12 & .99 & Moderate \\
\hline 5 & $\begin{array}{c}\text { Has wisdom in dealing with } \\
\text { the problems that face him }\end{array}$ & 3.07 & 1.06 & Moderate \\
\hline 1 & $\begin{array}{c}\text { Has the ability to plan } \\
\text { for his tasks }\end{array}$ & 2.93 & 1.06 & Moderate \\
\hline 15 & $\begin{array}{c}\text { Assigns tasks for the players } \\
\text { based on their abilities }\end{array}$ & 2.67 & .97 & Low \\
\hline 9 & $\begin{array}{c}\text { Shoulder the full responsibility } \\
\text { for his decisions }\end{array}$ & 2.66 & 1.11 & Low \\
\hline 13 & $\begin{array}{c}\text { Shares the players in decision } \\
\text { making }\end{array}$ & 2.59 & 1.02 & Low \\
\hline & The total domain & 3.67 & .51 & High \\
\hline
\end{tabular}

Table (5) illustrates that item number (12), which includes Serious in giving instruction to the players was ranked first with 'too high' degree and with an arithmetic mean of (4.48) and a standard deviation of $(0.7)$

The researcher believes that the seriousness in giving directions and the players' commitment to these directions are very important, especially in the competitions and championships where the coach is demanded to achieve championships and achievement, and more specifically that most of the coaches in these championships are local coaches with different levels and in case of failure in gaining the medals and the achieving the championships, they will be demands to give up. The coach is characterized by the good organization for his work and his 
continuous efforts to achieve his objectives as well as transmitting his respect for the laws and regulations in his work.

These results agree with Ribbon, 2001; Serpa, Pataco, Santos, 1991 which demonstrate that the behavior of the coach in the professional field is based on training, instructions and directions.

Item 13 which includes 'Shares the players in decision making' was in the last rank with a low degree and with an arithmetic mean of (2.59) and a standard deviation of (1.02).the researcher thinks that the local coach uses the management and leadership style that he believes to be suitable for the nature and conditions of the game of volleyball which 'in turn' reflects his philosophy and style of training and leading the team. The coach also doesn't involve all the players in decision making, but he limits that to a certain players in some training situations, whereas he makes the critical decisions during the formal championships and competitions.

The arithmetic mean for the estimates of the sample individuals in this domain as a whole was (3.67) with a standard deviation of (0.51). This corresponds to a high degree of estimating the leadership and management characteristics.

Table (6). The arithmetic means and standard deviations for the estimates of the study sample individuals regarding the scientific domain in a descending order

\begin{tabular}{|c|c|c|c|c|}
\hline No & Items & Md & Sd & $\begin{array}{c}\text { Characteristic } \\
\text { degree }\end{array}$ \\
\hline 3 & $\begin{array}{c}\text { Has the specialized scientific } \\
\text { knowledge in his work }\end{array}$ & 4.38 & .67 & Too high \\
\hline 5 & $\begin{array}{c}\text { Keep pace with the technological } \\
\text { advancement in the sport } \\
\text { of volleyball }\end{array}$ & 4.36 & .72 & Too high \\
\hline 1 & $\begin{array}{c}\text { Employs theoretical sciences } \\
\text { in his work }\end{array}$ & 4.35 & .70 & Too high \\
\hline 7 & $\begin{array}{c}\text { Able to gather data to implement } \\
\text { his tasks }\end{array}$ & 4.33 & .72 & Too high \\
\hline
\end{tabular}




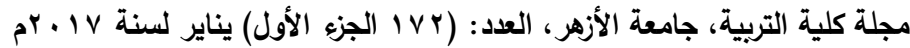

\begin{tabular}{|c|c|c|c|c|}
\hline \hline No & Items & Md & Sd & $\begin{array}{c}\text { Characteristic } \\
\text { degree }\end{array}$ \\
\hline 11 & $\begin{array}{c}\text { Familiar with management } \\
\text { experience in the sports activity. }\end{array}$ & 4.28 & .72 & Too high \\
\hline 13 & $\begin{array}{c}\text { Puts his training programs } \\
\text { according to scientific basis }\end{array}$ & 4.15 & .72 & Too high \\
\hline 9 & $\begin{array}{c}\text { Attends the scientific courses } \\
\text { that are relevant to the game }\end{array}$ & 4.04 & .79 & Too high \\
\hline 2 & $\begin{array}{c}\text { Pursue all the new advancement } \\
\text { in his field of work }\end{array}$ & 3.31 & 1.02 & Above average \\
\hline 4 & $\begin{array}{c}\text { Has a broad scientific culture } \\
\text { Has a comprehensive } \\
\text { view toward his job }\end{array}$ & 3.27 & 1.09 & $\mathbf{A b o v e}$ average \\
\hline 10 & $\begin{array}{c}\text { Purses the recent amendments } \\
\text { of the law of the game }\end{array}$ & 2.80 & 1.07 & Moderate \\
\hline 12 & $\begin{array}{c}\text { Good at using the new } \\
\text { advancement in the science } \\
\text { of training }\end{array}$ & 2.72 & .92 & Low \\
\hline 8 & $\begin{array}{c}\text { Makes us e of the } \\
\text { others' experiences }\end{array}$ & 2.54 & 1.00 & Low \\
\hline & The total domain & 3.65 & .49 & High \\
\hline
\end{tabular}

Table (6) illustrates that included, Has the specialized scientific knowledge in his work' was in the first rank with a high degree and with an arithmetic mean of (4.38) and a standard deviation of $(0.67)$. The researcher believes that the coaches have the Academic Qualifications in the field of specialization and they also have a continuous familiarity with the advancements in the field of the game.

The coach has an inclusive view because he pursues all the matters that relate to the players, the team and the game, and he also does the role of the manager, the psychologist the social and the technician for the team. the researcher Attributes that to the case that the Jordanian Federation of Volleyball in cooperation with the Center of preparing the Jordanian leaders, as well as in cooperation with the Regional Office in Cairo prepare well trained coaches and provide them with the scientific and practical knowledge through the intensity of championships at the level of 
local clubs or at the level of the Arab Championships, and this makes the Jordanian coaches familiar with everything that occurs regarding the game of training scientific and administrative changes.

Also, the majority of foreign coaches always seek to keep pace with the scientific and technical progress in the game, as well as pursuing all that is new, especially the amendments which are related to the laws of the game because the process of achievement and training require the coach to have the ability to develop plans and programs according to the scientific bases, therefore increases the degree of his knowledge, culture and specialization in the field of his work as a coach. Item number 8 which included 'Makes us e of the others' experiences' was in the last rank with a low degree with an arithmetic mean of (2.54) and a standard deviation of (1.00). There are so many coaches who depend on themselves, their experience as well as their knowledge and information and don't resort to the process of analysis in order not to be accused of imitation and scientific or technical theft by other coaches on the one hand. On the other hand, the players mayn't have information or knowledge about the operations of analysis of the other players, since this matter is exclusive for the technical staff of volleyball.

The arithmetic mean for the estimates of the sample individuals in this domain as a whole was (3.65) with a standard deviation of (0.49). This corresponds to a high degree of estimating the leadership and management characteristics.

To answer the second question "Are there statistically significant differences at the significance level $(\alpha \leq 0.05)$ in the leadership and management characteristics of coaches for the coaches of volleyball in Jordan from the perspective of the players Depending on the variables (the club, training age) Tables $(7,8)$ illustrated it. 
Table (7). The means and standard deviations for the estimates of the study sample individuals regarding the domains of leadership and management characteristics questionnaire for the coaches of volleyball Depending on the club variable

\begin{tabular}{|c|c|c|c|c|c|c|c|c|c|c|c|}
\hline \multirow[t]{2}{*}{ The club } & \multirow[t]{2}{*}{ No } & \multicolumn{2}{|c|}{$\begin{array}{c}\text { personal } \\
\text { domain }\end{array}$} & \multicolumn{2}{|c|}{$\begin{array}{c}\text { professional } \\
\text { domain }\end{array}$} & \multicolumn{2}{|c|}{\begin{tabular}{|c|} 
social \\
domain
\end{tabular}} & \multicolumn{2}{|c|}{$\begin{array}{c}\text { Scientific } \\
\text { domain }\end{array}$} & \multicolumn{2}{|c|}{$\begin{array}{c}\text { Then total } \\
\text { questionnaire }\end{array}$} \\
\hline & & Md & SD & Md & SD & Md & SD & Md & SD & Md & SD \\
\hline Al-Wehdat & 12 & 4.04 & .45 & 3.79 & .36 & 3.92 & .59 & 4.21 & .50 & 3.90 & .41 \\
\hline $\begin{array}{c}\text { Shabab } \\
\text { Al-Hussein }\end{array}$ & 12 & 3.74 & .31 & 3.78 & .43 & .90 & .46 & 3.65 & .23 & 3.77 & 20 \\
\hline Wadi Mousa & $\mathbf{1 0}$ & 3.87 & .62 & 3.81 & .49 & 3.80 & .41 & 3.69 & .42 & 3.80 & .44 \\
\hline Al-Baqaa & 10 & 3.69 & .29 & 3.66 & .43 & 3.80 & .61 & 3.77 & .35 & 3.72 & .35 \\
\hline Al-Karmel & 10 & 3.68 & .29 & 3.68 & .24 & 3.73 & .32 & 3.62 & .25 & 3.68 & .24 \\
\hline Aira & 8 & 3.39 & .86 & 3.42 & .76 & 3.47 & .76 & 3.60 & .67 & 3.46 & .74 \\
\hline Almahatta & 8 & 3.77 & .62 & 3.51 & .78 & 3.69 & .69 & 3.62 & .72 & 3.64 & .70 \\
\hline Deiralla & 8 & 3.76 & .46 & 3.82 & .26 & 3.94 & .30 & 3.77 & .30 & 3.82 & .19 \\
\hline Al-awda & 8 & 3.66 & .25 & 3.64 & .27 & 3.90 & .35 & 3.55 & .29 & 3.68 & .25 \\
\hline Maleeh & 8 & 3.74 & .57 & 3.73 & .55 & 3.79 & .51 & 3.72 & .42 & 3.74 & .48 \\
\hline Total & 94 & 3.73 & .56 & 3.67 & .51 & 3.75 & .56 & 3.65 & .49 & 3.70 & .49 \\
\hline
\end{tabular}

Table (8). The means and standard deviations for the estimates of the study sample individuals regarding the domains of leadership and management characteristics questionnaire for the coaches of volleyball Depending on the training age variable the

\begin{tabular}{|c|c|c|c|c|c|c|}
\hline \multirow{2}{*}{ The domain } & \multicolumn{2}{|c|}{$\begin{array}{c}\text { Less than 5 } \\
\text { years }(43 \\
\text { players }\end{array}$} & \multicolumn{2}{|c|}{$\begin{array}{c}\text { (5-10 years) } \\
\text { (35 players) }\end{array}$} & \multicolumn{2}{|c|}{$\begin{array}{c}\text { More than 10 } \\
\text { years }(16 \\
\text { players })\end{array}$} \\
\cline { 2 - 7 } & Mean & STD & Mean & STD & Mean & STD \\
\hline Personal & 3.75 & 0.54 & 3.73 & 0.48 & 3.65 & 0.77 \\
\hline
\end{tabular}




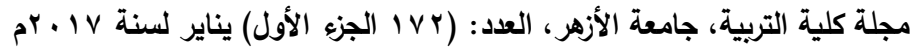

\begin{tabular}{|c|c|c|c|c|c|c|}
\hline Professional & 3.84 & $\mathbf{0 . 4 9}$ & 3.65 & $\mathbf{0 . 4 1}$ & 3.60 & $\mathbf{0 . 7 5}$ \\
\hline Social & 3.76 & $\mathbf{0 . 5 3}$ & 3.71 & $\mathbf{0 . 4 8}$ & 3.65 & $\mathbf{0 . 7 7}$ \\
\hline Scientific & $\mathbf{3 . 6 8}$ & $\mathbf{0 . 4 0}$ & $\mathbf{3 . 6 6}$ & $\mathbf{0 . 4 3}$ & $\mathbf{3 . 5 5}$ & $\mathbf{0 . 7 6}$ \\
\hline $\begin{array}{c}\text { The total } \\
\text { questionnaire }\end{array}$ & $\mathbf{3 . 7 3}$ & $\mathbf{0 . 4 5}$ & $\mathbf{3 . 6 9}$ & $\mathbf{0 . 4 0}$ & $\mathbf{3 . 6 1}$ & $\mathbf{0 . 7 3}$ \\
\hline
\end{tabular}

Tables $(7,8)$ illustrate that there are explicit differences between the means for the estimates of the sample individuals regarding the domains of the management and leadership characteristics questionnaire for the coaches of volleyball according to the variables of the study. In order to identify the levels of the statistical significance for these differences the multi variance analysis was used. Table (9) illustrates it.

Table (9). Multi variance analysis for the differences between the means for the estimates of the sample individuals in the domains of study Depending on the variables of study

\begin{tabular}{|c|c|c|c|c|c|c|}
\hline $\begin{array}{c}\text { Variation } \\
\text { source }\end{array}$ & Domain & $\begin{array}{c}\text { Squares } \\
\text { total }\end{array}$ & $\begin{array}{l}\text { Degree of } \\
\text { freedom }\end{array}$ & $\begin{array}{c}\text { Squares } \\
\text { mean }\end{array}$ & $\mathbf{F}$ & $P$ value \\
\hline \multirow{4}{*}{ The club } & Personal & 4.275 & 12 & 0.356 & 1.129 & .350 . \\
\hline & Professional & 2.880 & 12 & 0.240 & 0.877 & .573 \\
\hline & Social & 5.145 & 12 & 0.429 & 1.424 & .173 . \\
\hline & Scientific & 14.890 & 12 & .2411 & 5.236 & $0.02 *$ \\
\hline \multirow{4}{*}{$\begin{array}{c}\text { The } \\
\text { training } \\
\text { age }\end{array}$} & Personal & 0.710 & 2 & 0.035 & 0.112 & 0.894 \\
\hline & Professional & .2622 & 2 & .1311 & 4.128 & $0.08 *$ \\
\hline & Social & 0.533 & 2 & 0.267 & 0.886 & 0.416 \\
\hline & Scientific & 0.249 & 2 & 0.124 & 0.526 & .593 \\
\hline \multirow{4}{*}{ The error } & Personal & 24.614 & 78 & 0.316 & \\
\hline & Professional & 21.349 & 78 & 0.274 & & \\
\hline & Social & 23.478 & 78 & \multicolumn{3}{|c|}{0.301} \\
\hline & Scientific & 18.463 & 78 & \multicolumn{3}{|c|}{0.237} \\
\hline
\end{tabular}

Table (9) illustrate that there are no statistically significant differences between the average estimates of the study sample individuals at all the domains, except for the scientific domain due to the variable of club. In order to identify the sources of these differences Scheffe test was used table (1•) illustrated it. 
Table (10). Scheffe test for the differences between the means of the estimates of the sample individuals regarding the scientific domain depending of the club variable

\begin{tabular}{|c|c|c|c|c|c|c|c|c|c|c|}
\hline $\begin{array}{l}\text { The } \\
\text { club }\end{array}$ & $\begin{array}{c}\text { Al- } \\
\text { Wehdat }\end{array}$ & $\begin{array}{c}\text { Shabab } \\
\text { Al- } \\
\text { Hussein }\end{array}$ & $\begin{array}{l}\text { Wadi } \\
\text { Mousa }\end{array}$ & $\begin{array}{c}\text { Al- } \\
\text { Baqaa }\end{array}$ & $\begin{array}{c}\text { Al- } \\
\text { karmel }\end{array}$ & Aira & $\begin{array}{c}\text { Al- } \\
\text { Mahata }\end{array}$ & Deiralla & $\begin{array}{c}\text { Al- } \\
\text { awda }\end{array}$ & Maleeh \\
\hline Mean & 4.21 & 3.65 & 3.69 & 3.77 & 3.62 & 3.60 & 3.62 & 3.77 & 3.55 & 3.72 \\
\hline \begin{tabular}{|l|}
4.21 \\
\end{tabular} & $\mathbf{0}$ & -0.56 & -0.52 & -0.44 & -0.59 & -0.61 & -0.59 & -0.44 & -0.66 & -0.49 \\
\hline 3.65 & & $\mathbf{0}$ & 0.04 & 0.12 & -0.03 & -0.05 & -0.03 & 0.12 & -0.1 & 0.07 \\
\hline \begin{tabular}{|l|}
3.69 \\
\end{tabular} & & & $\mathbf{0}$ & 0.08 & -0.07 & -0.09 & $-\mathbf{- 0 . 0 7}$ & 0.08 & -0.14 & 0.03 \\
\hline 3.77 & & & & $\mathbf{0}$ & -0.15 & -0.17 & -0.15 & 0 & -0.22 & -0.05 \\
\hline \begin{tabular}{|l|}
3.62 \\
\end{tabular} & & & & & 0 & -0.02 & 0 & 0.15 & \begin{tabular}{|l|}
-0.07 \\
\end{tabular} & 0.1 \\
\hline \begin{tabular}{|l|}
3.60 \\
\end{tabular} & & & & & & $\mathbf{0}$ & 0.02 & 0.17 & -0.05 & 0.12 \\
\hline 3.62 & & & & & & & $\mathbf{0}$ & 0.15 & -0.07 & 0.1 \\
\hline \begin{tabular}{|l|}
3.23 \\
\end{tabular} & & & & & & & & 0.54 & \begin{tabular}{|l|}
0.32 \\
\end{tabular} & 0.49 \\
\hline 3.05 & & & & & & & & 0.72 & 0.5 & 0.67 \\
\hline \begin{tabular}{|l|}
3.77 \\
\end{tabular} & & & & & & & & $\mathbf{0}$ & -0.22 & -0.05 \\
\hline 3.55 & & & & & & & & & $\mathbf{0}$ & 0.17 \\
\hline \begin{tabular}{|l|}
3.72 \\
\end{tabular} & & & & & & & & & & $\mathbf{0}$ \\
\hline
\end{tabular}

Table (10) shows that there are statistically significant differences between the average of the club estimates (Al-Wehdat) on the one hand, and the average estimates of the clubs of on the other hand, in favor of the estimates of (Al-Wehdat). The researcher believes that the differences in leadership and management characteristics of coaches. That are attributed to the variable of the club were closely associated with the difference of the quality of the players in each club. This result agree with shatnawi, 2008 that the nature of the relationship that is prevalent between the coach and his players, which involves the style of dealing with them as well as what the coach achieves and does during training, which is reflected on the competitions and 
on the way of directing and dealing with them during championships.

Table (10) shows that there are no statistically significant differences between the average of the estimates of the study sample individuals at all the domains except for the professional domain attributed to the variable of training age. In order to identify the sources of these differences (Scheffe) test was used as illustrated in table (11).

Table (11). The results of (Scheffe) test for the differences between the averages of the sample individuals estimates regarding the professional domain Depending on the variables of study of training age.

\begin{tabular}{|c|c|c|c|c|}
\hline $\begin{array}{c}\text { More than } \\
\text { 10 years }\end{array}$ & 5-10 years & $\begin{array}{c}\text { Less than } \\
\text { 5 years }\end{array}$ & \multicolumn{2}{|c|}{ Training age } \\
\hline 3.60 & 3.65 & 3.84 & Mean & \\
\hline $0.24^{*}$ & $0.19 *$ & & 3.84 & Less than 5 years \\
\hline 0.05 & & & 3.65 & 5-10 years \\
\hline & & & 3.60 & More than 10 years \\
\hline
\end{tabular}

Table (11) shows that there are statistically significant differences between the average of the training age estimates (less than 5 years) on the one hand, and the average with training age estimates (5-10 years, and more than 10 years) on the other hand in favor of the estimates of the training age of (less than 5 years). The researchers believes that this category (less than five years) doesn't have the sufficient expertise to judge the coaches and the abilities. They think that these behaviors which are performed by coaches in dealing with them is the ideal and the positive ones that are based on high scientific bases which reflect the leadership and management characteristics that their coaches have; due to the lack of experience and knowledge of leadership and management characteristics that their coaches are supposed to have in comparison with their colleagues who coaches are experienced.

This result disagreed with Bani Hani, 2007; Shtiwi, 2012; Al-Lemon, 2013. Table (11) illustrates that there are no statistically significant differences between the average study sample estimates at all the domain of study, attributed to the 


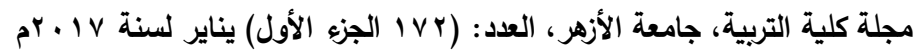

variable of training age. Three Way ANOVA analysis was conducted to identify the differences between the sample individuals estimates regarding the leadership and management characteristics for the coaches of volleyball according to the study variables as a whole. The results are illustrated in table (12).

Table (12). The results of Three Way ANOVA analysis for the differences between the means of the estimates of the sample individuals regarding the Depending on the variables of study

\begin{tabular}{|c|c|c|c|c|c|}
\hline Variables & $\begin{array}{c}\text { Squares } \\
\text { total }\end{array}$ & $\begin{array}{c}\text { Degree of } \\
\text { freedom }\end{array}$ & $\begin{array}{c}\text { Squares } \\
\text { mean }\end{array}$ & $\mathbf{F}$ & $\begin{array}{c}\text { Statistical } \\
\text { significance }\end{array}$ \\
\hline Club & 3.207 & 12 & .267 & 1.116 & .360 \\
\hline Training age & .223 & 2 & .111 & .465 & .630 \\
\hline Error & 18.682 & 78 & .240 & & \\
\hline Total & 1306.485 & 93 & & & \\
\hline
\end{tabular}

Table (12) illustrates that there are no statistically significant differences between the means of the estimates of the sample individuals regarding the leadership and management characteristics for the coaches of volleyball as a whole attributed to the study variables.

\section{Conclusions:}

The results of the study show that the leadership and management characteristics for the coaches volleyball were of a high degree, and they were arranged as follows: social characteristics, personal characteristics, professional characteristics, and scientific characteristics. The results also show that there are statistically significant differences in leadership and management characteristics for the responses of the players regarding the training age variable in favor of (less than 5 years).

\section{Recommendations:}

The study recommends planning for the training programs and the various sports events in Jordan, so that they are employed for the development of the content of coaches programs in order to ensure that there are in-depth studies for the concept of leadership by the Commission of developing coaches that belongs 
to the Center for the preparation of youth and sports leaders. Te study also recommends directing coaches of volleyball in Jordan towards taking advantage of the leadership and management characteristics and linking with the sporting achievements and gaining the championships as well as illustrating the importance of this in the national and international competitions.

\section{References:}

Abdel-Maksoud, A. (1995). Directing and adjusting the level of achievement path. Cairo: Al Khansaa Library.

Abu Zima', A. (2011). The impact of an educational program using special qualitative exercise in raising the level of skillful performance of the Butterfly swimming. Journal of Studies, 1(38), University of Jordan, Jordan.

Ali, M. (2003). The Leadership behavior for coaches and its relationship with the team coherence and achievement motivation among the players of sports teams in the Egyptian universities. Unpublished Master Thesis, University of Elmina, Elmina, Egypt

Al-Kubaisi, Y. (2010). Leadership behavior for the coaches of volleyball in Iraqi universities. Journal of sports culture, Mosul, Vol 2, p 2, 1-24.

Al-Lemon, M. (2013). The leadership and management characteristics of coaches athletics clubs in Jordan. Unpublished Master Thesis, faculty of Sports Science, Mu'tah University, Jordan.

AL -Massad, M. (2003). Effective Management, Lebanon, Beirut library.

Bani Hani, Z. (2007). The relationship of the leadership and management characteristics for coaches with team coherence among the handball players in Jordan. Unpublished PhD thesis. The University of Jordan, Jordan.

Chapman, P. (2001). Learning leadership. Translated by Mofida Naji Awdah, Riyadh: Dar Al-Maarifa. 




Cohen, W. (2001). The art of leadership. Translated Ibn Jarir, AlRiyadh Library: Jarir bookshop.

Kanaan, N. (1999). Managerial leadership. Oman: Dar El Thaqafa for publication and distribution.

Rosenberg, J. (1988). An Exploratory Study of coaching Leadership Styles on Team Climate، Achievement Motivation، and Performance in Woman Gymnastics. DAI-A49/09.p.2581

Serpa, S., Pataco, V., \& Santos, F. (1991). Leadership patterns in handball international competition. International Journal of Sport Psychology, 22, 78-89.

*Shatnawi, M. (2008). Leadership styles that are prevalent among the coaches of team games from the perspective of the players. Mu'tah Journal for Research and Studies, a series of humanitarian and social Science, Vol 24, p 2, S77-94

Shtiwi, T. (2012). Management characteristics among the players of the Premier League clubs for team games in Palestine. Journal of Educational and Psychological Studies, The Islamic University, Palestine, Vol 20, p 2, 521-547.

Sriboon, N. (2001). Coach Leadership behaviors ‘ team cohesion ‘ and athlete satisfaction in relation to the performance of athletes in the 1999 Rajabhat Games. Unpublished doctoral dissertation، The Florida State University، Tallahassee. 